\title{
Earth Sciences and Economics, a productive and dynamic interface awaiting exploration
}

\section{J.E. Vermaat ${ }^{*} \&$ M. Bokhorst}

Section Earth Sciences and Economics, Faculty of Earth and Life Sciences, VU University, De Boelelaan 1087, 1082 HV Amsterdam, the Netherlands.

* Corresponding author. Email: j.e.vermaat@vu.nl.

Manuscript received: August 2011, accepted: July 2012

\begin{abstract}
This paper sketches the historical common grounds of economics and earth sciences from their roots as scientific disciplines in the period of Enlightenment, and from a much earlier not necessarily scientifical commonality in the economic dependency of early societies on the prevalence of natural resources on the surface of the earth. It proceeds by stressing the commonality of the two disciplines in being empirical and positivistically mechanistic, without ignoring the major socio-cultural rift that occurs between their respective practitioners. The argument is put forward that societal problems, whether global or local, are often not straightforward and easily solved with the tools of a single discipline, and a plea is made for the combination of earth sciences and economics as candidates for a potent multi-disciplinary combination. Briefly, the BSc curriculum in Earth Sciences and Economics is justified and an accompanying research agenda is highlighted that starts from an empirical quantification of ecosystem services at the landscape scale of catchments.
\end{abstract}

Keywords: multi-disciplinarity, inter-disciplinarity, empiricism, the landscape scale, ecosystem services, natural resources

\section{Introduction}

Just as the other contributions to this special issue, this paper is written to highlight one of the contributions of Jef Vandenberghe to Earth Sciences as a broad collection of research and teaching activities at VU University. Jef Vandenberghe is a warm advocate and one of the initiators of research and teaching cooperation across a major disciplinary divide into social sciences, that is with economics and environmental studies. Although this was probably a bit off the main road of Earth Sciences, Jef Vandenberghe felt the urgency of a modernised broader scope to continue to be of interest to sufficient numbers of students and saw excellent opportunities for the development of a joint curriculum in 'Earth Sciences and Economics' with a supporting research agenda. He found active cooperation in both faculties responsible at the VU leading to the current programme. We are currently working on both the curriculum and research agenda and have gladly taken up the invitation of the guest editors to clarify our objectives and at the same time contribute to a Festschrift commemorating Jef's formal retirement.
We have developed this paper from the inaugural address of Vermaat (2011) and show that Earth Sciences and Economics may have more in common than one might think on first sight. We will argue for the necessity of multi-disciplinarity that maintains sufficient depth, and are keen to position our BSc and MSc curricula in the perspective of modern Earth Sciences as indicated in the research agenda described in KNAW (2011). Worldwide, again awareness is increasing of the natural limits of our single system earth that are under increasing pressure from human exploitation and interference (cf. Meadows et al. 1972 and Rockström et al., 2009). Societal problems often become apparent at the surface of the earth and equally often these are multi-facetted and 'wicked' (Rittel \& Weber, 1973), lacking the opportunity for a quickly engineered fix. Since societies cannot exist outside planet earth and its limiting natural resources, these pressing problems have a very clear economic as well as an earth sciences aspect. Also at a less grand scale, issues of the allocation and use of space, water, energy and other resources are probably better resolved when economic cost-benefit assessments incorporate the dynamics 
of system earth into the equation. We feel the need in society and science alike for experts that are well-versed in both disciplines and will argue below for what we call a 'narrow' multi-disciplinarity. We hope that with this we will contribute to the further development of the branches of the tree of science that share their interest in the earth as a complex object of study and at the same time meet what we feel as urgent societal needs.

\section{Commonalities and contrasts, sketching a historical background}

Whereas economics is currently considered part of social sciences and earth sciences are seen as empirical natural sciences, this separation was far less obvious during the $18^{\text {th }}$ and $19^{\text {th }}$ century, when these disciplines gradually did emerge. Blaise Pascal, Isaac Newton, Adam Smith, Thomas Malthus and their fellows shared an almost feverish struggle for deeper understanding as well as an optimism that they would be able to make major breakthroughs with their rational empiricism. This optimism radiates from the titles these authors attached to their often lengthy monographs (Table 1). Western science expanded almost exponentially in these years, with increasingly better calculus, theoretical conjectures and refutations bringer tighter logic, and a strong culture of correspondence and debate. One of the first geologists, Hutton, and one of the first economists, Adam Smith, came together to discuss in the Oyster Club in Edinburg on a weekly basis. Ball (2004) describes this succinctly: “... and for a heady half century or so there seemed to be no demarcations between physics, mathematics, economics, politics and sociology". We conclude that both scientific disciplines share distinctly positivist historical roots: we presume that science helps in the understanding and predicting of ultimately mechanistic systems underlying a complex and apparently chaotic physical reality (Frodeman, 1995). The same positivism is implied in our perspective that science can inform to improve the quality of policy and decision making, although its problems may be 'wicked'. Variability may limit our predictive capacity and has forced us to develop an array of statistical tools to break it down efficiently in meaningful partitions. Notably, these statistical tools do not differ that much across disciplines (e.g. Van Saase et al., 1990) and also have their roots in the time of Enlightenment (Table 1: Quetelet and several German colleagues, cf. Ball, 2004).

When we step further back into history there is no such thing as a juxta-position of earth and economics, actually we can be rather brief: without earth no economics. The earliest human societies critically depended on the benevolence and vagaries of system earth. Variability in the distribution and accessibility of natural resources across the surface of the earth determined if, when and where technological breakthroughs and human expansion were feasible. Hibbs \& Olsson (2004) related present economic wealth (as GDP) to the initial biogeographic richness of a region during the Neolithic agricultural revolution, more precisely to the availability of domesticable large mammals and grasses as well as climatic suitability. These authors could explain about half of the variability in GDP by geographic setting, though they ignored the covariance among variables studied (Table 2) and in their fullest model (last column, table 2), geographic setting did not add over and above the combination of the time since transition to sedentary agriculture and quality of governance and institutions, which together explained $80 \%$ of the variance. We conclude from this that it is remarkable that current economic performance of nations or regions still at least partly reflects the climatological and biogeographic conditions in Neolithic times. At the same

Table 1. A personal selection of key authorities that contributed to the development of Western science and the title of their major monographic contribution. Sources: Brinton et al. (1970), Edwards-Jones et al. (2000), Ball (2004).

\begin{tabular}{ll}
\hline Thomas Hobbes (1588-1679) & Leviathan (1651) \\
Rene Descartes (1596-1650) & Discours de la méthode pour bien conduire sa raison et chercher la vérité dans les sciences (1637) \\
Blaise Pascal (1623-1662) & Pensées (1669) \\
Christiaan Huijgens (1629-1695) & De ratiociniis in ludo aleae = Van reeckening in spelen van geluck (1657) \\
Isaac Newton (1642-1727) & Philosophiae Naturalis Principia Mathematica (1687) \\
Gottfried von Leibnitz (1646-1716) & Explication de l'arithmetique binaire (1703) \\
Francis Quesnay (1694-1774) & Tableau economique (1759) \\
Voltaire (1694-1778) & Candide, ou l'optimisme (1759) \\
David Hume (1711-1776)) & Treatise of human nature (1740) \\
Jean Jacques Rousseau (1712-1778) & Le contrat social (1752) \\
Adam Smith (1723-1790) & An inquiry into the nature and causes of the wealth of nations (1776) \\
Immanuel Kant (1724-1804) & Kritik der reinen Vernunft (1781) \\
James Hutton (1726-1797) & Theory of the earth, or an investigation of the laws observable in the composition, dissolution, \\
Thomas Malthus (1766-1834) & and restoration of land upon the Globe (1788) \\
Adolphe Quetelet (1796-1874) & An essay on the principle of population (1798) \\
\hline
\end{tabular}


Table 2. Selected regression fits among gross national product $\left({ }^{10} \log\right.$ of GDP, 1997), geographic setting ${ }^{a}$, prehistoric biogeographic richness ${ }^{b}$, transition to sedentary agriculture ${ }^{c}$ and quality of institutions ${ }^{d}$ for 112 nations (extracted from Table 3 in Hibbs \& Olsson, 2004; see also Olsson \& Gibbs, 2000). All variables except GDP have been standardised. Pressented are slopes \pm 1 SE and with significance ( $p$ ), as well as the explained variance of each regression model ( $r^{2}$-adjusted).

\begin{tabular}{|c|c|c|c|c|c|c|}
\hline Dependent variable $(y)$ : & $\begin{array}{l}\text { Biogeographic } \\
\text { richness }\end{array}$ & $\begin{array}{l}\text { Transition to } \\
\text { agriculture }\end{array}$ & Log GDP & Log GDP & $\begin{array}{l}\text { Quality } \\
\text { institutions }\end{array}$ & Log GDP \\
\hline \multicolumn{7}{|l|}{ Explanatory variable $(\mathrm{x})$ : } \\
\hline Geographic setting & $1.63 \pm 0.08(0.00)$ & $4.71 \pm 0.23(0.00)$ & $2.04 \pm 0.18(0.00)$ & - & $0.63 \pm 0.07(0.00)$ & $0.53 \pm 0.03(0.06)$ \\
\hline Transition to agriculture & - & - & - & - & - & $2.50 \pm 0.04(0.00)$ \\
\hline Quality institutions & - & - & - & $0.05 \pm 0.20(0.00)$ & - & $0.04 \pm 0.01(0.00)$ \\
\hline r2-adjusted & 0.79 & 0.78 & 0.52 & 0.67 & 0.43 & 0.80 \\
\hline
\end{tabular}

a Geographic setting was characterized as a compound index of Köppen climate, latitude and east-west position on a continent.

b Prehistoric biogeography combines the number of domesticable grass species (seed kernel $>10 \mathrm{mg}$ ) and large mammals (>45 kg). This indicator ranges from a maximum of 33 grasses en 9 mammals in western Eurasia to none of these in the Pacific.

c The moment of transition to sedentary agriculture was estimated from a non-linear curve fit for 6 independent regions with archeological evidence curve (in $1000 \mathrm{y}$ since $12,000 \mathrm{BP})$.

d Quality of institutions is a combination of 5 indicators obtained from a published rating.

time, the quality of current institutions appears equally influential in explaining the variability in the wealth of nations, which is a well studied subject in itself (Hall \& Jones, 1999; Easterly \& Levine, 2003).

At a global scale, the quality of our institutions may well become highly critical, when the notions of real 'limits to growth' (Meadows et al 1972; Turner, 2008), global warming and a maximum carrying capacity of system earth (expressed as an ecological footprint; WWF, 2010) become ever widely recognised, so that our global institutions develop mechanisms that generate societal trajectories towards true sustainablity. System earth provides humanity with a range of services, some of them are for free as yet (oxygen), others come at a (variable) cost and again others appear to become highly limited and costly (Rockström et al., 2009).

The availability of mineral phosphorus $(\mathrm{P})$ on earth may serve as an example. Phosphorus is a crucially important nutrient for agriculture, but unlike Nitrogen it is only available in finite deposits that are mined. Liu et al. (2008) budget that about half of the P currently mined annually is systematically lost again from the stocks and fluxes that are in our control. This $P$ is lost again into our soils, sediments and surface waters. Zapata and Roy (2004) estimate that 10 nations own $90 \%$ of the global stock, and claim that "based on current extraction rates and economic conditions in the 1990s, more than half of these countries will have exceeded the life of their reserves in less than 20 year". World market prices are on the increase and will make mineral fertiliser more expensive. On a global scale this implies a growing difficulty to feed humanity, notably because more will want a western style diet (Cordell et al., 2009; Aiking, 2010). Rockström et al. (2009) highlight Nitrogen as problematic, but are equally cautious when it comes to Phosphorus. The task to optimise the use of such increasingly scarce resources calls for an economics perspective as well as expertise.
The potential interference of climate change with our prevalent transport networks is another example. Climate change is foreseen to greatly alter the hydrology of major drainage networks across the world (IPCC, 2007). This will lead to major changes in land use distribution patterns (Verburg et al., 2008), but will also affect bulk transport across inland waterways (Jonkeren et al. 2007), with major economic consequences. River depth at Kaub controls the size of ships that can use the Rhine between Basel and the Ruhr-area. Climate change scenarios are used to predict plausible future low water frequencies. Consequent expected economic damage, expressed as changed freight prices per ton can be evaluated against engineering investments in channel deepening, regulating weirs or vessel design. Thus, economics and earth sciences interact in the optimisation for longer term sustainability (Jonkeren et al. 2007).

These two examples illustrate how earth sciences and economics play their interacting roles at a range of spatial scales, globally, regionally but also at the local scale of individual businesses, farmers and self-owning skippers, that compete for capital, land or other resources and face increasing costs, or at the scale of consumers that may face poverty or even malnutrition. In short, we feel that the world needs the expertise of both disciplines, and an acute awareness of their interactions. We have argued that they may share more than one might expect. At the same time, we cannot ignore the distance that has developed over two or three centuries of rifting divergence. Only limited overlap is apparent in the theories, paradigms, tools, empirical data bases, vocabulary, journals and first and foremost the framing and mind-set of the academics that complete our curricula. Attempts to bridge this gap meet with complications, Babylonian misunderstandings and frustration and the results are often frowned upon from one or the other side (e.g. Costanza et al., 1997 vs 
Fisher et al., 2008; or Bateman et al. 2010). Understanding each other simply takes time, patience and some devoted, cumulative trial-and-error efforts. Nuijten (2011) argues that "The little interaction that exists between the social and natural sciences is because of boundaries being maintained through differences in concepts, jargon, social networks and literature". The IPCC is a useful example where disciplinary integration appears to have worked out well (IPCC 2007). One common, but widely branched and turbulent effort of numerous colleagues is on its way to combine all necessary science to understand both sides of the equation: the complex physico-chemical dynamics of system earth on the one hand and the socio-economic ones of globalising societies across the world on the other. Without IPCC, we think that climate modelling would never have progressed so much, and the same can be said for scenario approaches in the social sciences.

\section{A plea for 'narrow' multi-disciplinarity in a bachelor curriculum}

Multi-disciplinarity as well as interdisciplinarity have been advocated before from different stand points, where interdisciplinarity is sometimes seen as more superior (Gannon 2005). When natural scientists were called in to solve society's environmental problems in the 1970's (Boersema \& Reinders 2010), they soon met with the limits of their discipline and found themselves in the Babylonic quagmire we just hinted at. Social scientists comparing performance of societies, nations or social strata (e.g. Hall \& Jones 1999) at the same time found they required to understand the physical geography of their subject matter. Similar ventures occur in public health (medicine vs social sciences; Berridge 2007) but also from across divides of rather more narrow disciplinary branches, such as molecular biology (Gannon 2005), landscape ecology (Tress et al. 2004), or seismology (Caputo \& Helly 2008).

We argue that an early acquaintance with the style of thinking and concepts of both social and natural sciences would be beneficial to the individual in a later professional life as an academic and to society in its need for solutions to complex, multi-disciplinary problems. We recognise at the same time that a broad interdisciplinarity without sound disciplinary rooting would run the risk of superficiality. We feel that a more narrow choice of only few disciplines across a promising disciplinary interface would validly overcome that risk. Based on several years experience with our current curriculum in Earth Sciences and Economics, we are confident that we have found one such an interface. At the same time, we do not imply that other similarly narrow cross-disciplinary curriculi could not be equally succesful. One could think of Ecology and Economics, or Earth Sciences and Public Administration. Our choice was stimulated by the willingness to cooperate in the two faculties. In preparation for our re-accreditation audit, we have searched around for similar BSc programmes offered at universities elsewhere (Faculty Earth and Life Sciences, 2011). Most are either weighed towards one discipline (e.g. Economic Geology, Physical Geography or Environmental Economics, Geography and Planning), or appear as a specialisation at the MSc level or as a Minor (e.g. Physical Geography). A notable exception is a BSc programme offered at McGill University in Canada, where a BSc Major 'Environment, Earth Sciences and Economics' focuses on natural resource management, mining and micro-economics.

Our graduates are well trained to considerable depth in both disciplines. The curriculum (Fig. 1) is necessarily selective on both sides to remain within the three years of a BSc. It focuses on spatial economics and surface earth sciences including field work and allows for a a structured series of integrative study elements. In these fieldworks we combine the outcomes of different mono-disciplinary views on a concrete spatial problem, and apply the 'community of learners' principle. For sound spatial analysis and integration, GIS is an important tool in our curriculum. Thus, different views first confront and then match their perspectives of scale, both spatially and temporally, to converge towards possible solutions. Whilst this gradually unfolds, also a joint integrating framework of analysis develops. Whilst our selectivity allows depth in the subjects of our choice, at the same time we cannot offer all aspects of economics or earth sciences. Compared to regular economics curricula we exclude finance, business and law, and compared to geology or earth sciences we offer petrology, geophysics and mining only to a very limited extent. Students can choose these subjects as electives. In our view, the curriculum in Earth Sciences and Economics delivers academics to society that have a mature and deep grasp of the content and necessary skills to find professional employment in both disciplinary domains, and more importantly, they have learned to combine these.

One may ask for some empirical evidence for our possibly optimistic view of our own course. Not too many of our BScgraduates have yet completed a full MSc as yet, but those that have and that we know of are employed as PhD (2), consultant (2), field worker environmental research (1) or environmental advisor (1) (Faculty of Earth and Life Sciences, 2011). For the cohorts that are still pursuing their MSc we have compiled statistics on a sample of courses (Table 3 ) of those that enrolled at our own university in the one year MSc Spatial, Transport and Environmental Economics (STREEM), as well as in the two year programmes in Hydrology and Earth Sciences and Economics or Earth Sciences. Based on the comparison of these 6 courses, we cannot conclude that ES\&E students performed worse than their mono-disciplinary fellows: the numbers are small, but in three out of the six courses ES\&E students performed significantly better, in two they were equal and in one course they scored worse (Table 3 ). In short, we feel that our optimism had some support in the numbers, whereas we remain are quite aware of the still short life span of our curriculum. 


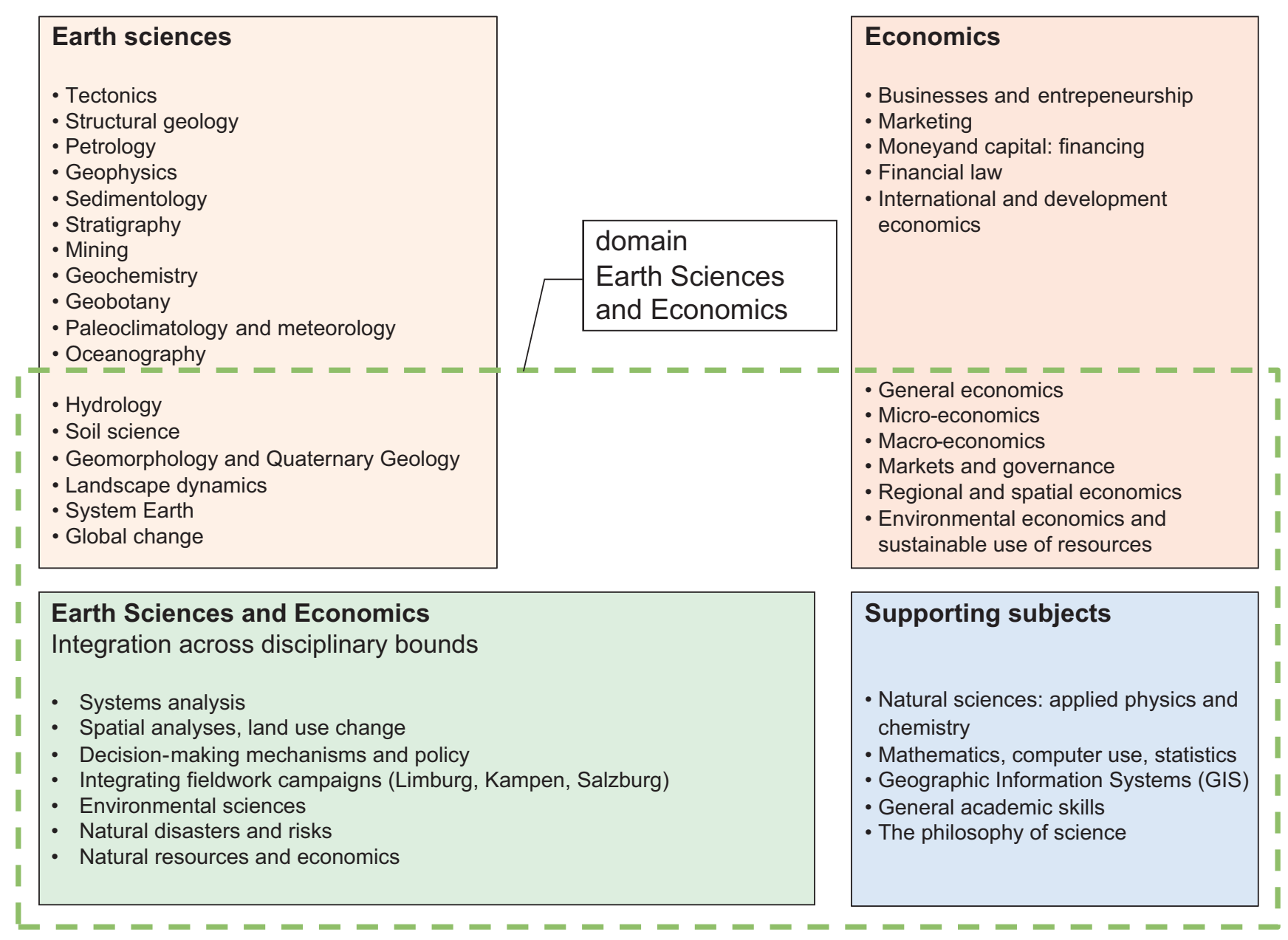

Fig. 1. The subjects taught in the BSc Earth Sciences and Economics at VU-University in relation to the domains of Earth Sciences and Economics.

Earth Sciences and Economics share some common roots, as we discussed above, but in our view they also share a positivist mechanistic systems perspective and a focus on quantitative analysis. This facilitates the bridging of disciplinary divides in the current combination. Nuijten (2011) argues that that economics is part of the social sciences, but observes that economics stands out out amongst the social sciences, because it interacts more frequently with the natural sciences than the other social sciences.

\section{A fitting research agenda and a perspective for research cooperation}

Vermaat (2011) argued for ecosystem services as the guiding theme to develop a research line in Earth Sciences and Economics and he demonstrated the applicability of the perspective in a number of existing research projects, ranging from costing different nutrient retention schemes in the Scheldt catchment (based on Vermaat et al., in revision) to the value of mangrove as natural hurricane barriers (based on Das \& Vincent 2009). Ecosystem services are seen as those benefits obtained from an ecosystem that enhance human welfare. This implies economic value, and attributing these values is a complex and interesting research effort in itself (e.g. MEA 2005; Wallace 2007; Fisher et al. 2008; Brouwer 2010). At the same time, the biogeochemical fluxes that underly or contribute to these final services have generally not yet been brought together in a consistent way to allow integration into an ecosystem services perspective. We put forward that the landscape scale of the catchments of medium sized rivers would be an appropiate spatial scale to attempt such integration, since it is fairly well studied, would allow for meaningful aggregation from economic data bases at subnational, regional scales, and leaves us handling space for interesting, comparative spatial contrasts among and within catchments. From an economic point of view, defining an appropriate spatial scale may appear less easy (Vermaat et al., 2005). Still, the catchment scale $(10-1000 \mathrm{~km})$ appears appropriate, since river networks have gravitated cities as major economic nodes and guided the development of economic transport networks (Fujita et al. 1999) into the upstream hinterland of major catchments (see also Sjöberg \& Sjöholm 2002). Jordan \& Fortin (2002) argued that "Economic scale, from a sustainability paradigm, should, therefore, incorporate spatial and temporal dimensions as they are constrained by geophysical and ecosystem processes". At the same time, ecologists and economists alike argue for operationalisation and more 
Table 3. Student grades from selected subjects in the specialistic master programmes Hydrology, Paleoclimatology and Spatial, Transport and Environmental Economics (STREEM) of academic year 2010-2011 and 2011-2012 at VU University Amsterdam. The table compares results of students with a specialistic BSc-background in Earth Sciences or Economic and Business Administration to students with an interdisciplinary BSC 'Earth Sciences and Economics' background. Grades are presented as average \pm 1 standard error (number of replicates) marking range is 1-10). Also presented are the levels of significance $(p)$ of t-tests assuming unequal variances.

\begin{tabular}{llll}
\hline a. & $\begin{array}{l}\text { Background } \\
\text { Bsc Economics }\end{array}$ & $\begin{array}{l}\text { Background } \\
\text { ES\&E }\end{array}$ & $\begin{array}{l}\text { p } \\
\text { (t-test) }\end{array}$ \\
\hline STREEM & & & \\
Environmental Economics & $7.0 \pm 0.2(32)$ & $7.1 \pm 0.2(7)$ & 0.79 \\
\hline b. & $\begin{array}{l}\text { Background BSc } \\
\text { Earth Sciences }\end{array}$ & ES\&E & \\
\hline $\begin{array}{l}\text { Hydrology } \\
\text { Ecohydrology }\end{array}$ & $6.3 \pm 0.2(8)$ & $7.8 \pm 0.2(3)$ & 0.02 \\
$\begin{array}{l}\text { Catchment Response } \\
\text { Analyses }\end{array}$ & $7.2 \pm 0.2(9)$ & $8.6 \pm 0.2(3)$ & 0.002 \\
$\begin{array}{l}\text { Regional Hydrology } \\
\text { Paleoclimatology }\end{array}$ & $6.4 \pm 0.2(34)$ & $7.6 \pm 0.2(4)$ & 0.02 \\
$\begin{array}{l}\text { Sedimentary Environments } \\
\text { Modern Climate Systems }\end{array}$ & $6.5 \pm 0.2(8)$ & $6.4 \pm 0.2(10)$ & 0.90 \\
\hline
\end{tabular}

rigorous quantification of ecosystem services (Daily et al. 2009). We currently develop a research line where geophysical and biogeochemical fluxes in landscapes in catchments are quantified and integrated to answer the questions: a) what produces which service where; b) what are the temporal dynamics; c) where exactly in the landscape does society benefit from this; and d) to what sector or stratum of society does the benefit accrue? We do so in close cooperation with economists, earth scientists, landscape ecologists and geographers at the VU and beyond, we seek partners to extend our reach and learn from their expertise and experience, and look forward to share our thoughts.

\section{In conclusion}

Designing and implementing a research programme at a disciplinary interface is a challenge we look forward to meet. In a world where political and economic realities appear to become ever more transient and global change affects climate, land use, land cover and human occupation patterns probably within decades, the interface between earth sciences and economics would be both highly relevant and interesting to operate on. The research group Earth Sciences and Economics will do so in the coming years and hopes to contribute also by training academics that are well equipped to operate at this interface as well. We thank Jef Vandenberghe for his katalytic contribution to our work.

\section{Acknowledgements}

We thank the guest editors Hans Renssen and Kees Kasse, responsible for this special issue, for inviting us to write this contribution. Frank Bruinsma (Spatial Economics, VU University) critically read a draft of this text and the anonymous reviewers have helped us to sharpen our phrasing and remove some redundancies. Last, but not least, we thank Jef for his long sight and constructive optimism in getting the programme in shape and populated.

\section{References}

Aiking, H., 2010. Future protein supply. Trends in Food Science and Technology 22: 112-120.

Ball, $P$., 2004. Critical mass, how one thing leads to another. Random House (London).

Bateman, I.J., Mace, G.M., Fezzi, C., Atkinson, G. \& Turner, R.K., 2010. Economic analysis for ecosystem service assessments. Enviromental Resource Economics 48: 177-218.

Berridge, V., 2007. Multidisciplinary public health: what sort of victory? Public Health 121: 404-408.

Boersema, J.J., 2007. Principlesof environmental sciences Springer.

Brinton, C., Christopher, J.B. \& Wolff R.L., 1970. A history of civilization Part 2. Renaissance to Bismarck. Elseviers World History. Dutch Edition by J. Winkler en S.J. de Vries, Elsevier (Amsterdam).

Brouwer, R., 2010. Payments for ecosystem services: making money talk. Inaugural address VU University, Amsterdam, 15 april 2010.

Caputo, R. \& Helly, B., 2008. The use of distinct disciplines to investigate past earth quakes. Tectonophysics 453: 7-19.

Cordell, D., Drangert J.0. \& White S., 2009. The story of phosphorus: global food security and food for thought. Global Environmental Change 19: 292-305.

Costanza, R., D'Arge, R., De Groot, R., Farber, S., Grasso, M., Hannon, B., Limburg, K., Naeem, S., O'Neill, R.V., Paruelo, J., Raskin, R.G., Sutton, P. \& Van den Belt, M., 1997. The value of the world's ecosystem services and natural capital. Nature 387: 253-260.

Das, S., Vincent \& J.R., 2009. Mangroves protected villages and reduced death toll during Indian super cyclone. Proceedings National Academy Sciences of the USA 106: 7357-7360.

Daily, G., Polasky, S., Goldstein, J., Kareiva, P., Mooney, H., Pejchar, L., Ricketts, T., Salzman, J. \& Shallenberger, R., 2009. Ecosystem services in decision making: time to deliver. Frontiers in Ecology and the Environment 7: 21-28.

Easterly, W. \& Levine, $R$., 2003. Tropics, germs, and crops: how endowments influence economic development. Journal of Monetary Economics 50: 3-39.

Edwards-Jones, G., Davies, B. \& Hussain, S., 2000. Ecological economics, an introduction. Blackwell (London).

Faculty of Earth and Life Sciences, 2011. Self-evaluation Bachelor Curriculum Earth Sciences and Economics: VU University, Amsterdam, the Netherlands, $27 \mathrm{pp}$ and 13 annexes. (In Dutch) 
Fisher, B., Turner, R.K., Zylstra, M., Brouwer, R., De Groot, R., Farber, S., Ferraro, P., Green, R., Hadley, D., Harlow, J., Jefferiss, P., Kirkby, C., Morling, P., Mowatt, S., Naidoo, R., Paavola, J., Strassburg, B. \& Yu Balmford, A.D., 2008. Ecosystem services and economic theory: integration for policy-relevant research. Ecological Applications 18: 2050-2067.

Fujita, M., Krugman, P. \& Venables, A.J., 1999. The spatial economy: Cities, regions, and international trade. MIT Press, Cambridge MA, USA, 367 pp.

Gannon, F., 2005. Multidisciplinarity: by fiat or need? EMB0 reports 6: 1105.

Hall, R.E. \& Jones, C.I., 1999. Why do some countries produce so much more output per worker than others? Quarterly Journal of Economics 114: 83-116.

Hibbs, D.A. \& Olsson, 0., 2004. Geography, biogeography, and why some countries are rich and others poor. Proceedings of the National Academy of Sciences of the USA 101: 3715-3720.

IPCC, 2007. Climate change 2007: synthesis report. www.ipcc.org

Jonkeren, 0., Rietveld, P. \& Ommeren, J., 2007. Climate change and inland waterway transport: welfare effects on low water levels on the river Rhine. Journal of Transport Economics and Policy 41: 387-411.

Jordan, G.J. \& Fortin, M.J., 2002. Scale and topology in the ecological economics sustainability paradigm. Ecological Economics 41, 361-366.

KNAW, 2011. Agenda 2020, a vision of the earth sciences as a discipline. KNAW, Amsterdam, the Netherlands. (In Dutch)

Liu, Y., Villalba, G., Ayres, R.U. \& Schroder, H., 2008. Global Phosphorus flows and environmental impacts from a consumption perspective. Journal of Industrial Ecology 12: 229-247.

Meadows, D.H., Meadows, D.L., Randers, J. \& Behrens III, W.W., 1972. The limits to growth. New York: Universe Books.

Nuijten, E., 2011. Combining research styles of the natural and social sciences in agricultural research. NJAS - Wageningen Journal of Life Scinces 57: 197-205.

Olsson, 0. \& Hibbs, D.A., 2000. Biogeography and long-run economic development. Working Papers in Economics no 26, Department of Economics, Göteborg University, Sweden.

Rittel, H. \& Webber, M., 1973. Dilemmas in a general theory of planning. Policy Sciences 4: 155-169.

Rockström, J., Steffen, W., Noone, K., Persson, A., Chapin, F.S., Lambin, E.F., Lenton, T.M., Scheffer, M., Folke, C., Schellnhuber, H.J., Nykvist, B., De Wit, C.A., Hughes, T., Van der Leeuw, S., Rodhe, H., Sorlin, S., Snyder, P.K., Costanza, R., Svedin, U., Falkenmark, M., Karlberg, L., Corell, R.W., Fabry, V.J., Hansen, J., Walker, B., Liverman, D., Richardson, K., Crutzen, P. \& Foley, J.A., 2009. A safe operating space for humanity. Nature 461: 472-475.

Sjöberg, O. \& Sjöholm, F., 2002. Common ground? Prospects for integrating the economic geography of geographers and economists. Environmental Planning A 34: 467-486.

Tress, G., Tress B. \& Fry, G., 2004. Clarifying integrative research concepts in landscape ecology. Landscape Ecology 20: 479-493.

Turner, G., 2008. A comparison of the limits to growth with thirty years of reality. CSIRO Working paper Series 2008-09, CSIR0 (Canberra) Australia.

Van Saase, J.L.C.M., Noteboom, W.M.P. \& Vandenbroucke, J.P., 1990. Longevity of men capable of prolonged vigorous physical exercise: a 32 year follow up of 2259 participants in the Dutch eleven cities ice skating tour. British Medical Journal 301: 1409-1411.

Verburg, P.H., Eickhout, B. \& Van Meijl, H., 2008. A multi-scale, multi-model approach for analyzing the future dynamics of European land use. Annals of Regional Science 42: 57-77.
Vermaat, J.E., Eppink, F., Van den Bergh, J.C.J.M., Barendregt, A. \& Van Belle, J., 2005. Aggregation and the matching of scales in spatial economics and landscape ecology: empirical evidence and prospects for integration. Ecological Economics 52: 229-237.

Vermaat, J.E., 2011. Solid earth, volatile economics, a boundary or a mixture? Inaugural address, January 25, 2011, VU University, Amsterdam. (In Dutch)

Vermaat, J.E., Broekx, S., Van Eck, B., Engelen, G., Hellmann, F., De Kok, J.L., Van der Kwast, H., Maes, J., Salomons, W. \& Van Deursen, W., in revision. Nitrogen source apportionment for the catchment, estuary and adjacent coastal waters of the Scheldt. Ecology \& Society.

Wallace, $K_{\bullet}, 2007$. Classification of ecosystem services: problems and solutions. Biological Conservation 139: 235-246.

$W W F, 2010$. Living planet report 2010, biodiversity, biocapacity and development. Gland, Switzerland: www.footprintnetwork.org.

Zapata, F. \& Roy R.N., 2004. Use of phosphate rocks for sustainable agriculture. FA0 Fertilizer and Plant Nutrition Bulletin 13, FA0 (Rome): 1-148. 